\title{
FLUID INCLUSIONS IN CAVITY QUARTZ CRYSTALS IN RAPAKIVI FROM LUUMÄKI, SOUTHEASTERN FINLAND
}

\author{
MATTI POUTIAINEN
}

\begin{abstract}
POUTIAINEN, MATTI, 1991. Fluid inclusions in cavity quartz crystals in rapakivi from Luumäki, southeastern Finland. Bull. Geol. Soc. Finland 63, Part 2, $87-93$.

Fluid inclusions in selected cavity quartz crystals in rapakivi granite from Luumäki, southeastern Finland, were studied by microthermometric methods. Two different compositional types of fluid inclusions were identified: (I) low- to intermediate-salinity mixed $\mathrm{H}_{2} \mathrm{O}-\mathrm{CO}_{2}$ inclusions (1.8-5.9 eq.wt. $\% \mathrm{NaCl}$ ) and (II) intermediate-salinity aqueous inclusions (3.6-5.2 eq.wt. $\% \mathrm{NaCl}$ ). The different fluid inclusion types occur in different stages of the host crystal growth allowing their paragenetic classification as primary, pseudosecondary and secondary. The temperatures of total homogenization of Type I primary, pseudosecondary and secondary inclusions range from 343 to $372^{\circ} \mathrm{C}, 221$ to $236^{\circ} \mathrm{C}$ and from 160 to $174^{\circ} \mathrm{C}$, respectively. The pseudosecondary inclusions of Type II composition show filling temperatures of 214 to $251^{\circ} \mathrm{C}$.
\end{abstract}

Key words: fluid inclusions, quartz, granites, rapakivi, microthermometry, Luumäki, Finland

Matti Poutiainen: Department of Geology, University of Helsinki, Snellmaninkatu 3, SF 00170 Helsinki, Finland

\section{Introduction}

The Luumäki morion-type smoky quartz occurrence is located in southeastern Finland within the Wiborg rapakivi batholith (Fig. 1). In 1986 idiomorphic quartz crystals weighing up to 260 $\mathrm{kg}$ were found at Luotoistenkylä, in the parish of Luumäki, during road construction. Crystals were loose in the ground and their original site was already destroyed by the road machinery. It is evident, however, that the crystals with welldeveloped faces have grown on the walls of large cavity in the rapakivi granite. Probably, they have formed in the central chamber of a granite pegmatite. Originally the cavity was lined with quartz, microcline (verified by X-ray; M. Lehtinen, pers. comm., 1991) and albite crystals. Simi- lar, but smaller quartz crystal cavities have been described by Kinnunen et al. (1987). The samples studied in this work were collected by Dr. M. Lehtinen (Geological Museum) and Mr. H. Koivisto (Finnish State Computer Centre).

\section{Fluid inclusion types}

A paragenetic classification of observed fluid inclusion types in the idiomorphic quartz crystals was established on the basis of their mode of occurrence (Fig. 2). The nomenclature and diagnostic criteria used are those of Roedder (1984). The studied crystals were $<5.0 \mathrm{~cm}$ long and had a maximum diameter of $2.0 \mathrm{~cm}$. Fluid inclusions were examined in doubly-polished 


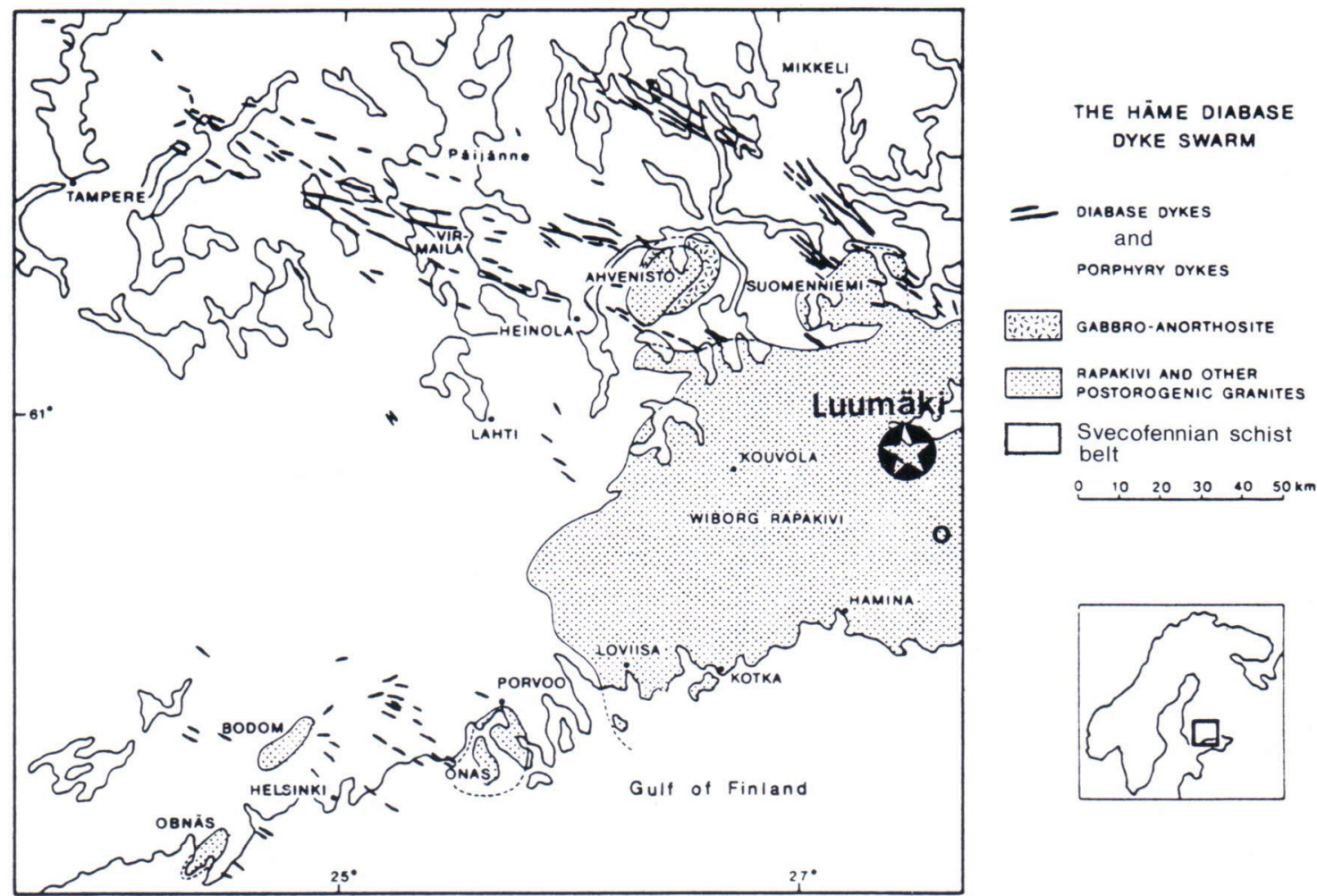

Fig. 1. Location and geological map of the Luumäki cavity quartz occurrence in southeastern Finland (modified from Laitakari and Leino 1989).

plates, 0.3 to $1.0 \mathrm{~mm}$ thick, cut perpendicular and parallel to the $\underline{c}$-axis of the crystals. These inclusions fall into two different compositional types: (I) $\mathrm{H}_{2} \mathrm{O}-\mathrm{CO}_{2}$ and (II) $\mathrm{H}_{2} \mathrm{O}$.

Primary inclusions (P) with estimated filling degree (F) of 0.4 to 0.7 (i.e. $60-30$ vol. $\% \mathrm{CO}_{2}$ rich vapor) occur in the cores of quartz crystals, usually as single inclusions of negative crystal shape (Figs. 3-1 and 3-2). They are of Type I composition, and vary in longest dimension from 18 to $210 \mu \mathrm{m}$ (mean $50 \mu \mathrm{m}$ ). The degree of fill of Type I-II inclusions were determined at T $>31^{\circ} \mathrm{C}$. Some larger $(>100 \mu \mathrm{m})$ primary inclusions are surrounded by a halo or ring of small inclusions (Fig. 3-3; see Sterner and Bodnar 1989). These small inclusions lie in a plane perpendicular to $\underline{\mathrm{c}}$, and are not three-dimensional features. The inclusions with such halos are ex- cluded from the present fluid inclusion data. The only daughter mineral observed in some primary inclusions is probably nahcolite (see Rankin and Le Bas 1974). It occupies $\sim 4$ vol. \% of the total volume of the inclusions. The mineral has very high birefringe and marked difference in refractive indeces. In some orientations, when the mineral is rotated in polarized light, it becomes almost invisible, whilst in other orientations it shows a considerable relief.

Pseudosecondary inclusions (PS) are of both Type I and Type II composition. They occur in separate inclusion trails (see Fig. 2). Type I inclusions are relatively large $(13-500 \mu \mathrm{m}$, mean $100 \mu \mathrm{m}$ ), with estimated degree of fill varying from 0.0 to 0.1 (Fig. 3-4). They frequently exhibit features commonly attributed to leakage and necking-down phenomenon. The inclusions 


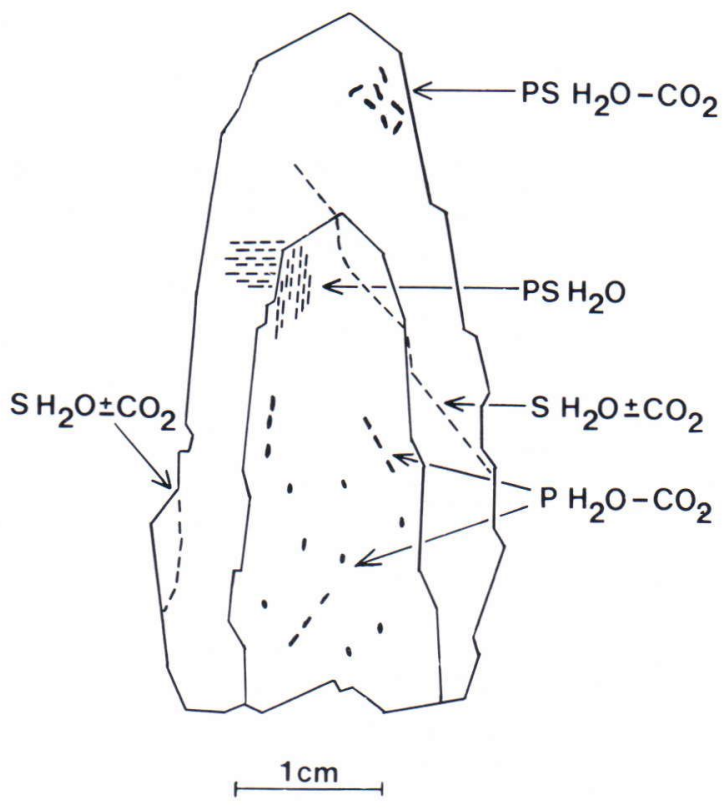

Fig. 2. Euhedral quartz crystal from Luumäki, sectioned parallel to the crystallographic $\underline{\mathrm{c}}$-axis, showing fluid inclusion generations identified by their spatial relationship to growth surface and healed fractures. $\mathrm{P}=$ primary, $\mathrm{PS}=$ pseudosecondary and $\mathrm{S}=$ secondary inclusions.

are rare and they occur as planar arrays near the top of quartz crystals. Type II inclusions, with constant degree of fill of 0.9 , and with negative crystal shape, occur outside the cores of quartz crystals, usually as planes inside a single growth zone or as trails with relatively widely spaced in-. clusions (Fig. 3-5). The inclusion trails may crosscut the growth zone boundaries, but they end within the crystal. The size of the inclusions vary between 8 and $155 \mu \mathrm{m}$ (mean $30 \mu \mathrm{m}$ ). Some inclusion planes contain both liquid-rich $(\mathrm{F}=0.9)$ and monophase vapor inclusions $(\mathrm{F}=0.0)$. The crushing test (Roedder 1970) of the inclusions do not indicate the presence of any compressed gases (i.e. $\mathrm{CO}_{2}$ or $\mathrm{CH}_{4}$ ).

Secondary inclusions (S), with estimated degree of fill from 0.9 to 0.95 , occur in healed microfractures crosscutting the growth zones (Fig. 3-6). Sometimes the trails end at crystal surface (see Fig. 2). Vapor bubble of the inclu- sions contain some dissolved $\mathrm{CO}_{2}$ as indicated by the crushing test. Thus, they are of Type I composition. The size of the inclusions vary between 20 and $200 \mu \mathrm{m}$ (mean $40 \mu \mathrm{m}$ ).

\section{Analytical procedure}

Microthermometric determinations were performed on a Fluid Inc. heating/freezing stage (»the Reynolds stage», see Shepherd et al. 1985). The stage was calibrated against ice bath $\left(0^{\circ} \mathrm{C}\right)$, liquid nitrogen $\left(-196.8^{\circ} \mathrm{C}\right)$ and a set of synthetic fluid inclusion standards (Syn Flinc). Taking account of reproducibility and read-out precision, the recorded temperatures of phase transitions below $+30^{\circ} \mathrm{C}$ have an estimated uncertainty of $0.2^{\circ} \mathrm{C}$, whereas measurements below $400^{\circ} \mathrm{C}$ are accurate to $3.0^{\circ} \mathrm{C}$.

\section{Microthermometric data}

Complete microthermometric data of the observed fluid inclusion types encountered in the studied quartz crystals, supplemented with some additional parameters, are presented in Table 1.

In Type I inclusions ( $\mathrm{P}$ and PS) the melting temperatures of $\mathrm{CO}_{2}$ phase $\left(\mathrm{T}_{\mathrm{m}} \mathrm{CO}_{2}\right)$ vary from -54.0 to $-56.5^{\circ} \mathrm{C}$. Thus, the inclusions do not contain additional components such as $\mathrm{CH}_{4}$ or $\mathrm{N}_{2}$ in vapor phase. These components would cause $\mathrm{T}_{\mathrm{m}} \mathrm{CO}_{2}$ to be lower than $-56.6^{\circ} \mathrm{C}$, the triple point of pure $\mathrm{CO}_{2}$. Salinity of the aqueous phase was determined from the temperatures of final clathrate melting (Collins 1979). The clathrate melting temperatures of inclusions varies from +7.0 to $+9.3^{\circ} \mathrm{C}$, which is equivalent to $1.8-5.9$ eq.wt. $\% \mathrm{NaCl}$. Primary inclusions have somewhat lower salinity than the pseudosecondary inclusions. $\mathrm{CO}_{2}$ homogenization temperatures of these inclusions indicate a density of 0.20 to $0.17 \mathrm{~g} / \mathrm{cc}$ for the $\mathrm{CO}_{2}$ phase. The $\mathrm{CO}_{2}$ phase homogenizes invariably into the vapor state. Total homogenization of primary in- 


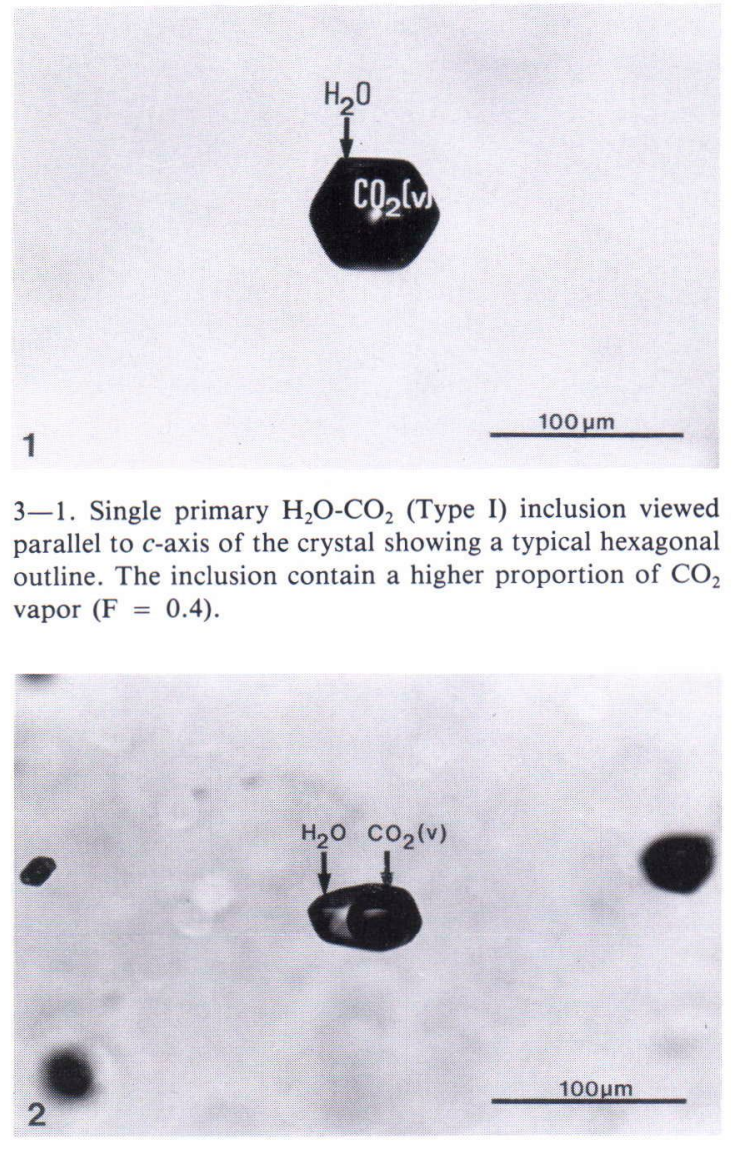

3-2. Primary $\mathrm{H}_{2} \mathrm{O}-\mathrm{CO}_{2}$ (Type I) inclusion showing a lower proportion of $\mathrm{CO}_{2}$ vapor $(\mathrm{F}=0.7)$.

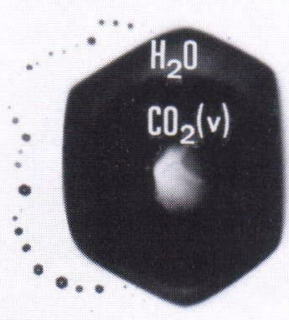

3

$100 \mu \mathrm{m}$

3-3. Primary $\mathrm{H}_{2} \mathrm{O}-\mathrm{CO}_{2}$ (Type I) inclusion surrounded by a halo of compositionally similar but smaller inclusions, from the core of a quartz crystal.

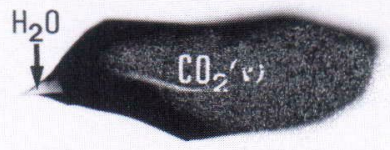

4

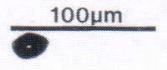

3-4. Pseudosecondary $\mathrm{H}_{2} \mathrm{O}-\mathrm{CO}_{2}$ (Type I) inclusion showing only a small proportion of aqueous solution in reentrants at the ends of the inclusion (right end of the inclusion is slightly out of focus).

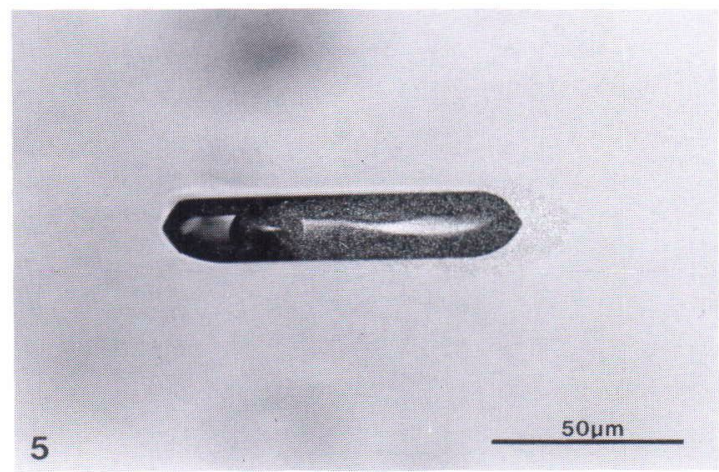

3-5. Pseudosecondary pure aqueous inclusion (Type II) viewed perpendicular to the c-axis of the crystal.

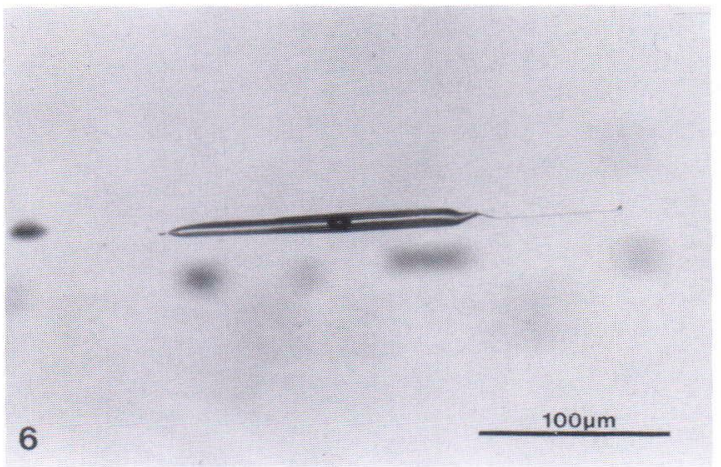

3-6. A needle-like secondary $\mathrm{H}_{2} \mathrm{O} \pm \mathrm{CO}_{2}$ (Type I) inclusion having a long very thin "tail» on the right, indicating necking-down of the inclusion.

Fig. 3. Paragenetic fluid inclusion types observed in the Luumäki smoky quartz crystals. 
Table 1. Summary of fluid inclusion data. $\mathrm{P}=$ primary, $\mathrm{PS}=$ pseudosecondary and $\mathrm{S}=$ secondary inclusions. $\mathrm{F}=$ degree of fill as a volumetric proportion of liquid $\left(\mathrm{V}_{\mathrm{L}}\right)$ relative to total volume $\left(\mathrm{V}_{\text {Tот }}=\mathrm{V}_{\mathrm{L}}+\mathrm{V}_{\mathrm{V}}\right)$ of inclusion $\left(\mathrm{F}=\mathrm{V}_{\mathrm{L}} / \mathrm{L}+\mathrm{V}_{\mathrm{V}}\right)$ determined at $>31^{\circ} \mathrm{C}$. $\mathrm{T}_{\mathrm{m}}=$ temperature of melting $\left({ }^{\circ} \mathrm{C}\right)$ of $\mathrm{CO}_{2}$, clathrate $\left(\mathrm{CO}_{2} \cdot 5.75 \mathrm{H}_{2} \mathrm{O}\right)$ and $\mathrm{H}_{2} \mathrm{O}$. $\mathrm{T}_{\mathrm{h}}=$ temperature of homogenization of the stated pair of phases. The phase into which homogenization occurs is marked in the brackets ( $\mathrm{L}=$ liquid, $\mathrm{V}=$ vapor $)$. Sty $=$ salinity expressed as weight $\% \mathrm{NaCl}$-equivalent, $\mathrm{d}=$ fluid density in $\mathrm{g} / \mathrm{cc}$.

\begin{tabular}{|c|c|c|c|c|}
\hline $\begin{array}{l}\text { Paragenetic } \\
\text { classification }\end{array}$ & $\mathrm{P}$ & PS & PS & S \\
\hline $\begin{array}{l}\text { Composition } \\
\text { F }\end{array}$ & $\begin{array}{c}\mathrm{H}_{2} \mathrm{O}-\mathrm{CO}_{2} \\
0.4-0.7\end{array}$ & & $\mathrm{H}_{2} \mathrm{O}$ & $\mathrm{H}_{2} \mathrm{O}\left( \pm \mathrm{CO}_{2}\right)$ \\
\hline $\begin{array}{l}\mathrm{F} \\
\mathrm{T}_{\mathrm{m}} \mathrm{CO}_{2}\end{array}$ & $\begin{array}{c}0.4-0.7 \\
-54.0--56.4\end{array}$ & $\begin{array}{c}0.0-0.1 \\
-56.2--56.5\end{array}$ & $\begin{array}{l}0.9 \\
-\end{array}$ & $\begin{array}{c}0.9-0.95 \\
-\end{array}$ \\
\hline $\mathrm{T}_{\mathrm{m}} \mathrm{H}_{2} \mathrm{O}$ & - & - & $-2.6--3.3$ & $-2.3--3.2$ \\
\hline $\mathrm{T}_{\mathrm{m}} \mathrm{CLAT}$ & $8.0-9.3$ & $7.0-7.3$ & - & - \\
\hline $\mathrm{T}_{\mathrm{h}} \mathrm{CO}_{2}$ & $21-23(\mathrm{~V})$ & $15-16(\mathrm{~V})$ & - & - \\
\hline $\mathrm{T}_{\mathrm{h}} \mathrm{H}_{2} \mathrm{O}$ & - & - & $214-251(\mathrm{~L})$ & $160-174(\mathrm{~L})$ \\
\hline $\mathrm{T}_{\mathrm{h}} \mathrm{H}_{2} \mathrm{O}-\mathrm{CO}_{2}$ & $343-372(\mathrm{~V} / \mathrm{L})$ & $221-236(\mathrm{~V})$ & - & - \\
\hline Sty & $1.8-4.1$ & $5.3-5.9$ & $3.6-5.2$ & $3.5-5.0$ \\
\hline wt. $\% \mathrm{CO}_{2}$ & $8-23$ & $60.5-100$ & - & $?$ \\
\hline $\mathrm{dCO}_{2}$ & 0.20 & 0.17 & - & - \\
\hline $\mathrm{dH}_{2} \mathrm{O}-\mathrm{CO}_{2}$ & $0.52-0.76$ & $0.17-0.25$ & - & - \\
\hline $\mathrm{dH}_{2} \mathrm{O}$ & - & - & $0.84-0.86$ & $0.93-0.95$ \\
\hline
\end{tabular}

clusions occurs both into the vapor state, and into the liquid state by solution of $\mathrm{CO}_{2}$ into the $\mathrm{H}_{2} \mathrm{O}$ phase in the same temperature interval, because of different $\mathrm{CO}_{2} / \mathrm{H}_{2} \mathrm{O}$ ratios. The temperatures of total homogenization of these inclusions range from 343 to $372^{\circ} \mathrm{C}$. Pseudosecondary inclusions (Type I) have considerably lower total homogenization temperatures $\left(221-236^{\circ} \mathrm{C}\right)$ than the primary inclusions. The homogenization occurs into the vapor state. The single daughter mineral (nahcolite?) encountered in some primary inclusions dissolved at $175^{\circ} \mathrm{C}$. It did not re-precipate from the enclosed fluid on cooling. From the solubility data for $\mathrm{NaHCO}_{3}$ (Crawford, 1981), the dissolution value of $175^{\circ} \mathrm{C}$ is equivalent to $33 \mathrm{wt} . \%$ $\mathrm{NaHCO}_{3}$.

Salinity of Type I secondary and Type II pseudosecondary inclusions have been calculated from the equation given by Potter et al. (1978). Homogenization of these inclusions occurs into the liquid state. There is an almost complete overlap of total homogenization temperatures for the both types (I-II) of pseudosecondary inclusions. The salinity of the PS (Type II) and S inclusions are almost identical. The vapor phase of secondary inclusions does not contain enough $\mathrm{CO}_{2}$ to form neither clathrate nor a visible phase of liquid $\mathrm{CO}_{2}$ during freezing. The temperatures of homogenization of these inclusions range from 160 to $174^{\circ} \mathrm{C}$. The relationship between total homogenization temperature of Type I mixed $\mathrm{H}_{2} \mathrm{O}-\mathrm{CO}_{2}$ inclusions ( $\mathrm{P}$, PS and $\mathrm{S}$ ) and the homogenization temperature of Type $\mathrm{II}_{2} \mathrm{O}$ inclusions (PS) versus salinity of the aqueous phase are shown in Fig. 4.

\section{Discussion}

The primary Type I inclusions in the cores of the quartz crystals indicate the conditions under which the enclosing host were formed. The total homogenization temperatures of 343 to $372^{\circ} \mathrm{C}$ represent the minimum temperature of crystallization. The pseudosecondary inclusions (Type I and II) outside the cores have trapped during fracturing of still growing crystals. Their homogenization temperatures of 214 to $251^{\circ} \mathrm{C}$ would correspond to a temperature decrease of $\sim 120$ to $130^{\circ} \mathrm{C}$ between the cores and the outer rims of the crystals, presuming that the pressure did not change. Moreover, there has occurred an 


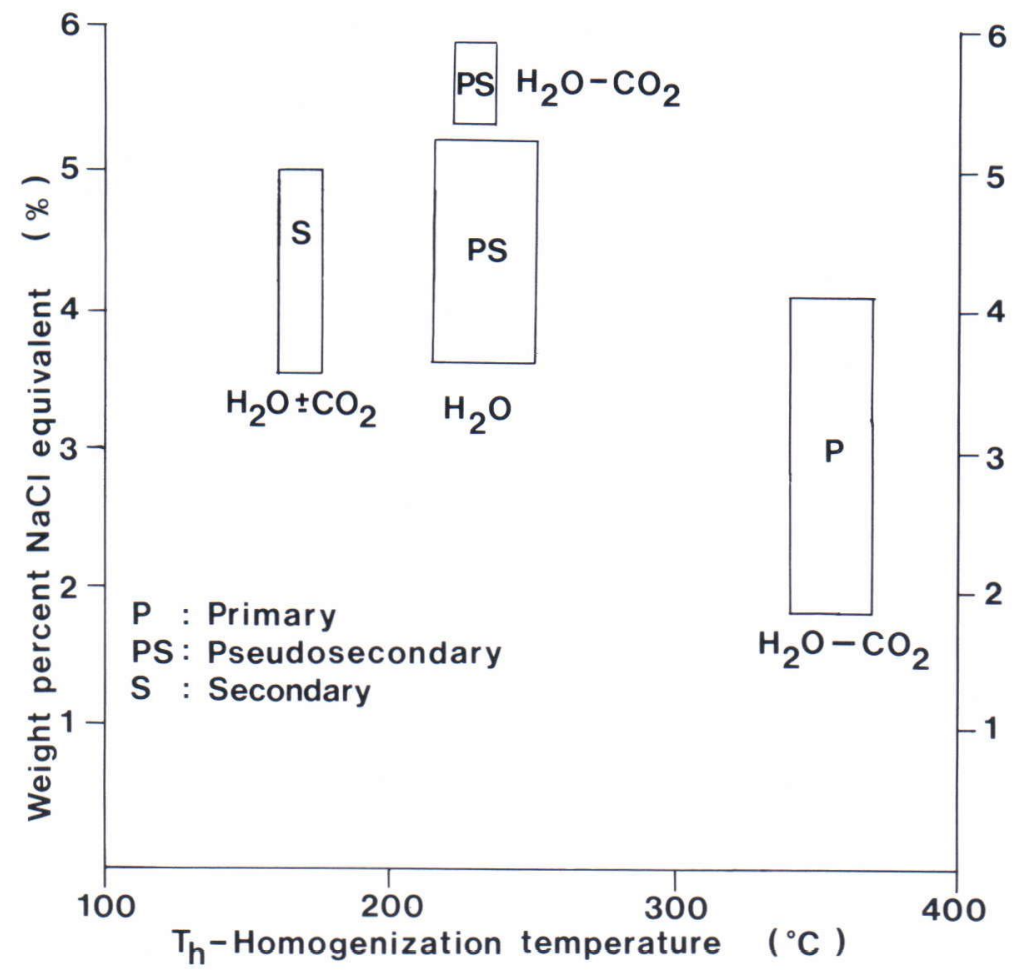

Fig. 4. Diagram showing relationship between total homogenization temperature of $\mathrm{H}_{2} \mathrm{O}-\mathrm{CO}_{2}$ inclusions (Type I; P, PS and S) and homogenization temperature of $\mathrm{H}_{2} \mathrm{O}$ inclusions (Type II; PS) versus salinity of the aqueous phase. introduction of intermediate-salinity pure aqueous fluid as indicated by the pseudosecondary Type II inclusions. The secondary Type I inclusions, which have formed after the crystallization of the bulk of the host, set the minimum temperature of the last observed hydrothermal fluid at 160 to $174^{\circ} \mathrm{C}$. The salinity of the fluids has increased during the crystal growth. This is most conspicious in the aqueous phase of Type I primary (1.8-4.1 eq.wt. \% $\mathrm{NaCl})$ and pseudosecondary $(5.3-5.9$ eq.wt. $\% \mathrm{NaCl})$ inclusions. The pseudosecondary Type I and II inclusions with overlapping homogenization temperatures, can not be considered as a pair of inclusions derived from unmixing of the primary Type $\mathrm{I} \mathrm{H}_{2} \mathrm{O}-\mathrm{CO}_{2}$ fluid. This is because the Type II inclusions do not contain any $\mathrm{CO}_{2}$ in the vapor phase and because of the higher salinity of the Type I inclusions. Thus, the salinity increase is not a result of fractionation of the salt into the aqueous phase (i.e. effervescence) of low-salinity primary Type
I $\mathrm{H}_{2} \mathrm{O}-\mathrm{CO}_{2}$ fluid.

The observed fluid inclusion types ( $\mathrm{P}, \mathrm{PS}$ and S) do not show evidence of any kind of immiscibility (i.e. boiling or effervescence). Thus, in the case of primary Type I inclusions, the true trapping pressure exceeded the vapor pressure of the fluid (i.e. $>250$ bars) at the temperatures of homogenization (Bowers and Helgeson 1983). The pressure estimate ( $\mathrm{Pf}$ ) for the formation of the Wiborg rapakivi batholith is $1.0 \mathrm{~kb}$ (Vorma 1971). If we assume a pressure range from 0.25 to $1.0 \mathrm{~kb}$, and neglect the effect of $\mathrm{CO}_{2}$, the temperature correction as a result of this pressure (i.e. " pressure correction»; see Potter 1977) would yield a temperature range of crystallization from 384 to $493^{\circ} \mathrm{C}$. Kinnunen et al. (1987) report corrected crystallization temperatures for the Haikonvuori quartz crystals of 312 to $464^{\circ} \mathrm{C}$. The primary inclusions in quartz crystals from Luumäki differ from those described by Kinnunen et al. (op. cit.) because of their relatively high 
$\mathrm{CO}_{2}$ content (8-23 wt. $\left.\%\right)$.

The different fluid inclusion generations (P, PS and $\mathrm{S}$ ), observed in the Luumäki quartz crystals, represent sequential trapping of fluids at different times under different P-T conditions, which might be related to emplacement of the Wiborg batholith in several intrusion phases. The variable gas/liquid ratios of part of the pseudosecondary Type I-II inclusions are attributed to leakage and necking-down.

\section{References}

Bowers, T.S. \& Helgeson, H.C., 1983. Calculation of the thermodynamic and geochemical consequences of nonideal mixing in the system $\mathrm{H}_{2} \mathrm{O}-\mathrm{CO}_{2}-\mathrm{NaCl}$ on phase relations in geologic systems: metamorphic equilibria at high pressures and temperatures. Am. Mineral. 68, pp. 1059-1075.

Collins, P.L.F., 1979. Gas hydrates in $\mathrm{CO}_{2}$-bearing fluid inclusions and the use of freezing data for estimation of salinity. Econ. Geol. 73, pp. 1435-1444.

Crawford, M.L., 1981. Phase equilibria in aqueous fluid inclusions. Mineral. Assoc. Canada Short Course Handbook 6, pp. 75-100.

Kinnunen, K., Lindqvist, K. \& Lahtinen, R., 1987. Fluid history from crystal cavities in rapakivi, Pyterlahti, southeastern Finland. Bull. Geol. Soc. Finland 59, Part I, pp. $35-44$.

Laitakari, I. \& Leino, H., 1989. A new model for the emplacement of the Häme diabase dyke swarm, Central Finland. Geol. Surv. Finland Spec. Paper 10, pp. 7-8.

Potter, II, R.W., 1977. Pressure correction for fluid inclusion homogenization temperatures based on the volumetric properties of the system $\mathrm{NaCl}-\mathrm{H}_{2} \mathrm{O}$. U.S. Geol. Survey J. Res. 5, pp. 603-607.
Acknowledgements. I wish to thank Dr. M. Lehtinen (Geological Museum) for providing quartz samples used in this study. Prof. I. Haapala (Department of Geology), Dr. K. Kinnunen (Geological Survey) and Dr. E. Roedder (Harvard University) reviewed the preliminary draft of the paper and provided many interesting and helpful comments. I would like to express my appreciation to above mentioned persons and especially to Dr. E. Roedder.

Potter, II, R.W., Clynne, M.A. \& Brown, D.L., 1978. Freezing point depression of aqueous sodium chloride solutions. Econ. Geol. 73, pp. 284-285.

Rankin, A.H. \& Le Bas, M.J., 1974. Nahcolite $\left(\mathrm{NaHCO}_{3}\right)$ in inclusions in apatites from some E. African ijolites and carbonatites. Mineral. Mag. 39, pp. 564-570.

Roedder, E., 1970. Application of an improved crushing microscope stage to studies of the gases in fluid inclusions. Schweiz. Mineral. Petrogr. Mitt. 50, pp. 41-58.

Roedder, E., 1984. Fluid inclusions, Reviews in Mineralogy Vol. 12. Mineral. Soc. America, $644 p$.

Shepherd, T., Rankin, A.H. \& Alderton, D.H.M., 1985. A practical guide to fluid inclusion studies. Blackie, $230 \mathrm{p}$.

Sterner, S.M. \& Bodnar, R.J., 1989. Synthetic fluid inclusions - VII. Re-equilibration of fluid inclusions in quartz during laboratory-simulated metamorphic burial and uplift. J. metamorphic Geol. 7, pp. 243-260.

Vorma, A., 1971. Alkali feldspars of the Wiborg rapakivi massif in southeastern Finland. Bull. Comm. Geol. Finlande 246, $72 \mathrm{p}$.

Received February 20, 1991

Revision accepted June 10, 1991 